Www.ibpas.com

\title{
AN ANATOMICAL ANALYSIS ON GARBHA POSHANA THROUGH MOTHER'S NUTRITION
}

\author{
SHARMA $S^{1}$ AND BANDAPALLE DN ${ }^{2 *}$ \\ 1: PG Scholar, Department of Rachana Sharira, Parul Institute of Ayurved, Vadodara, \\ Gujarat India
}

2: Professor \& Guide, HOD Department of Rachana Sharira, Parul Institute of Ayurved, Vadodara, Gujarat India

*Corresponding Author: Dr. Bandapalle Dattu Narayanrao: E Mail: Bandapalle.dattu18576@paruluniversity.ac.in Received 12 ${ }^{\text {th }}$ Dec. 2021; Revised 14 ${ }^{\text {th }}$ Jan. 2022; Accepted $7^{\text {th }}$ Feb. 2022; Available online $5^{\text {th }}$ March. 2022

https://doi.org/10.31032/IJBPAS/2022/11.3.1004

\section{ABSTRACT}

Garbha Poshana principles are focused on foetal nutrition and the child's reliance on his or her mother for appropriate growth and development. Many changes occur both within and outside the foetus while the Garbha (foetus) develops inside the Garbhaashaya (uterus). Garbha Poshana is caused by the development of structures such as the Garbha Nabhi Nadi (umbilical cord) and the Apara (placenta). The Garbha Poshana is demonstrated by the mother and foetus exchanging resources.

Keywords: Garbha poshana, Garbha, foetal Nourishment etc.

\section{INTRODUCTION}

The ultimate goal of every living species is to live as long as possible (foetus) inside the Garbh Ashaya (uterus). Since immortality is dubious, reproduction is the next best choice. All living organisms exist via their children as a result of reproduction. ${ }^{1}$ All survival skills are handed down through the generations via genes, which alter both within and outside the foetus at the same time. Garbha Poshana is caused by the development of structures such as the Garbha Nabhi nadi (umbilical cord) and the Apara (placenta). The transfer of inherited structural units. The survival of the maternal progeny is dependent on the health of both nutritional and waste components. Proper diet and care are essential for good health. This starts in 
the womb of the mother ${ }^{2}$. The foetus receives sustenance and care from its mother from the time of conception till delivery. The notion of Garbha Poshana (foetal nutrition)and the concept of Garbha matru parathantrata were proposed by ancient Ayurvedic physicians (dependency of child on its mother forits proper growth and development). ${ }^{3}$ Many changes occur both within and outside the foetus while the Garbha (foetus) develops inside the garbh ashaya (uterus). Garbha Poshana is caused by the development of structures such as the Garbha Nabhi nadi (umbilical cord) and the Apara (placenta). The Garbha matru parathantrata is demonstrated by the interchange of both nutritional and waste elements between the mother and the foetus.

\section{AIM \& OBJECTIVES}

To evaluate the concepts of Garbha Poshana specified in Ayurvedicliterature w.s.r. fetal nourishment in Rachana Sharir

\section{METHODOLOGY}

Ayurvedic literature texts, such as portions from Charaka Samhita- Shareera sthana. The data was collected, evaluated, and analyzed from the Susrutha SamhitaShareera sthana as well as from Anatomy literature.

\section{GARBHA POSHANA}

The umbilical cord is linked to the mother's rasavaha nadi (maternal part of the placenta) and transports ahara rasa virya (nutrition) from the mother to the foetus, according to Acharya Susrutha. This indirect source of nutrients helps the foetus grow ${ }^{4}$. The embryo receives sustenance through the tiriyak gata (obliquely running) rasavaha dhamanis (vessels carrying rasa) which run through all parts of the body and provide life to the embryo from the moment of conception until the various portions of the body and their subdivisions have appeared. The Garbha Nabhi nadi, which acts as a route for the rasa (lymph-chyle) generated in the mother's body, is responsible for the foetus' growth and development. ${ }^{5}$ This nutrition of the foetus from the mother's body begins the moment the baby is born alive and continues until the infant is no longer attached to the mother. The foetus gets all of its nutrition from the mother's metabolic products, and it also breathes and sleeps in tandem with her. ${ }^{6}$

The foetus, according to Acharya Charaka, is not thirsty or hungry. All of the Garbha's actions are reliant on the mother. The process of upasneha (exudation) and upasweda nourishes the foetus (thermoregulation). ${ }^{7}$ Some organs are fully developed, while others are not; the foetus obtains nutrition from exudation, which occurs sometimes through the romakupa (hair follicles)and sometimes through the 
umbilical cord's channels On one side, the foetus' umbilical cord is linked to the umbilicus, while on the other, it is attached to the placenta. ${ }^{8}$ Through syantana sira, the placenta is linked to the matru hrdaya (mother's heart) (pulsating vessels). The matru hrdaya is thought to fill the apara with rasa and sarvarasa (all tastes), promoting the foetus' bala (strength) and Varna (complexion). ${ }^{9}$ The Rasa of a pregnant lady, according to Acharya Charaka, serves three purposes: Swashareera pushti (self-nourishment), Stanyaaya (lactation), and Garbha- vridhi (Growth of fetus). The foetus is reliant on the mother for sustenance and continues to live inside the uterus.

The foetus, which is located inside the uterus, sleeps when the mother sleeps and wakes up when she wakes up. The foetus' actions are not independent, and it is dependent on the mother's nourishment for its moistness and dryness from the moment of conception7. When the foetus' organs and components are fully developed, a tube linking the foetus' umbilicus to the apara, which is then attached to the mother's heart, is produced. ${ }^{10}$ The nutritious part of the meal is transferred from the mother's heart through the dhamanis to the apara and then to the Nabhi. It then travels to the pakwaashaya (intestine), where it is digested further by kaya Agni (digestive juices). According to Vagbhata in Aga Hrdaya, manifestation of gaatrapanchaka (5 bodily parts) and sarva- sushma-anga (all minute organs) begins during the third month of pregnancy. A tube linking the fetus's Nabhi (umbilicus) and the mother's hrdaya develops, which is responsible for the flow of matur ahara rasa (essence of the mother's food) and the fetus's nourishment. This method is comparable to the kedaara eva kulya nyaya method (irrigation of a cornfield by means of numerous canals). ${ }^{11}$

\section{ACCORDING TO MODERN ANATOMY}

According to contemporary research, the nutrition of a foetus is discussed in numerous sources based on its various phases of development. This may be divided into three stages: after fertilization until the end of implantation, after implantation until placenta formation, and after placenta formation. $^{12}$ The zygote created after fertilization undergoes cleavage, and the growing embryo takes nutrients from the contents of the ovum's cytoplasm during this stage. The developing embryo is also lubricated and fed by the uterine tube secretions as it travels from the site of fertilization to the site of implantation. The secretions of the trophoblast cells contribute to the feeding of the embryo when the implantation process begins. The embryo is primarily fed after implantation by the secretions of the trophoblast cells, which gather inside the yolk sac. The 
foetal circulation is established once the placenta is formed. The placenta gives nutrients and oxygen to the developing embryo.

\section{RESULT OF FETAL NOURISHMENT}

The relationship between the child and the mother is defined by all bhrihatrayees as the former's reliance on the latter for food through ahara rasa and a safe environment for its growth within the uterus. ${ }^{13}$ The foetus is fed by the cytoplasmic contents of the ovum, trophoblast cells, uterine secretions, and the placenta in contemporary embryology.

\section{DISCUSSION}

\section{GARBHA POSHANA}

Garbha Poshana is a concept (fetal nourishment) Garbha Poshana is mostly triggered by the rasa received from the mother. Because of its apakwa dhathu, Garbha demands rasa from his mother (under developed organs). The ambu component of the garbhotpathi samagri is aahara rasa (Ritu, kshetra, ambu and bija).After reaching the hrdaya, it is known as rasa dhathu, and this rasa is sent to the entire body by rasavahadhamanis. This rasa also enters the apara during pregnancy, which transfers the essence to the Garbha Nabhi nadi. ${ }^{14}$ According to Charaka Acharya, the umbilical veins (sira) transport the rasa to the Garbha Nabhi, where it joins the foetus' systemic circulation. Garbha's shareera dhathu is nourished by this rasa.

Nutrient components absorbed by intestinal villi are transported to the liver via the portal vein, according to contemporary interpretation. It is detoxified in the liver and then sent to the lungs via the heart, where it is oxygenated. The heart's pumping motion subsequently distributes this oxygenated and nutrient-rich blood throughout the body. At various stages of development, the foetus receives nutrients from a variety of sources. The cytoplasmic contents of the ovum, as well as the secretions from the uterine tube, supply the embryo with the required nutrients shortly after fertilization until implantation. Secretions from trophoblastic cells, the uterine tube, and endometrial cells supply sustenance from the moment of implantation until the creation of the placenta. The foetal circulation is developed when the placenta is formed, and it becomes the foetus' primary nutrient supply.

\section{GARBHA-MATRURELATION}

The Garbha is completely reliant on the mother's diet for moisture and dryness from the momentof conception. The apara and the Garbha Nabhi nadi are the conduits via which the mother and child communicate. The foetus takes all of its nutrition from the mother's metabolic products, and it also 
breathes and sleeps in tandem with the mother, according to Acharya Susruta. When a kid is in the womb, Acharya Charaka says that the infant's shud pipasa is dependent on its mother.

There is also no aahara paka, which means there is no malaor mutra formation. ${ }^{15}$ There is no metabolic activity inside the Garbha since there is apakwa dhathu. Major functions like as oxygenation, digesting, and absorption are yet to begin. Nutrition through eating and oxygenation through breathing will begin shortly after delivery. Aside from Garbha-vridhi, the pregnant woman's Rasa also functions as Swa-shareera pushti (body nourishment) and Stanyaaya (Lactation). The foetus is dependent on the mother for sustenance and continues to live within the uterus. The upasneha, upasweda, and romakupa are the major sources of nutrition.

\section{PERCEPTION OF UPASNEHA AND UPASWEDA: -}

UPASNEHA- Exudation is the process of moisture or other liquid substances being discharged via pores. The process of diffusion between maternal and foetal blood in the placenta area mayoccur here.

UPASWEDA- Sweating is the meaning of the term. Thermoregulation is defined as generating a warm, comfortable environment for the growing baby within the uterus that promotes comfort,protection, and growth, similar to that of an incubator.

ROMAKUPA: Some rasa is thought to be absorbed into the foetus through the hair follicles, however absorption through hair follicles is said to be insignificant in current times.

The action of Kayaagniof Garbha in the region of pakwaashaya for digestion is discussed by Acharya Vagbhata. Because just Sara bhaga (essence) of the mother's aahara rasa enters the foetus, the operation of kaya Agni is unclear. The process of nutrition is illustrated in Aga Hrdaya using the example of kedaara eva kulya nyaya, which may be translated as systemic foetal circulation. The relationship between the kid and the mother has been described by all bhrihatrayees as the former's reliance on the latter for food and a safe environment in which to develop.

Matrujadi shad bhava and panchabhootatmaka bhava, in addition to rasa, impact the development of the foetus. Their impact is mostly on neurological issues such as sensory deficiency, tactile feelings, and the development of personality.

Maatruja aahara vihara dosa14 refers to the mother's inappropriate diet and regimen during Garbhadana kala (pregnancy) as one of the contributing causes for Garbha vikruti (foetal abnormalities) and Anuvamshika vyadhi (foetal deformities) 
(congenital disorders). Because rasa is the foetus' primary source of nutrition, understanding Garbha Poshana can aid in both the prevention and treatment of Garbha vikruti. Including antenatal care regimens such as Garbha raksha vidhi, garbhini raksha vidhi, garbhini charya, Garbha raksha kashaya, and otherscan also assist improve the quality of future children.

\section{CONCLUSION}

The idea of Garbha Poshana proposes that the aahara rasa from the mother is transmitted to the Garbha through two anatomical structures, namely the para and the Garbha Nabhi nadif, for its growth and development. The notion of Garbha matru parathantrata refers to a child's shud, pipasa, wetness, and dryness being dependent on its mother. Upasneha, upasweda, and kedaara eva kulya nyaya are phrases used to describe the process of nutrition. Knowledge of different nutrition sources may aid in antenatal care for the prevention and treatment of Garbha vikruti.

\section{Conflict of Interest - Nil}

Source of Support-None

REFERENCES

[1] P. Ray, H N Gupta, M Roy, (1993), Susrutha Samhita- A scientific synopsis, Indian National Science Academy, New Delhi, $2^{\text {nd }}$ edition, pp: 21.

[2] Acharya Agnivesha. Acharya
Charaka, Vaidya Yadavji Trikamji

Acharya, editors. Acharya

Chakrapani Dutta. Charaka

Samhita with Ayurvedadipika

Commentary. Varanasi:

Chaukhambha Sanskrit Sansthan; 2008, pp: 334.

[3] Ram Karan Sharma, Vaidya Bhagwan Dash, Caraka Samhita, (2002), Chowkhamba Sanskrit Series Office, Varanasi, $7^{\text {th }}$ edition, pp: 443.

[4] Ram Karan Sharma, Vaidya Bhagwan Dash, Caraka Samhita, (2002), Chowkhamba Sanskrit Series Office, Varanasi, $7^{\text {th }}$ edition, pp: 444.

[5] Prof. K. R. Srikantha Murthy, Astanga Samgraha of Vagbhata (1996), Chaukhamba Orientalia publishers Varanasi, pp: 24.

[6] Prof. K. R. Srikantha Murthy, Aṣ̣āniga Samgraha of Vagbhata (1996), volume 2 Chaukhamba Orientalia publishers Varanasi, pp: 24.

[7] Prof. K.R. Srikantha Murthy, Vagbhata's Astanga Hrdayam, (1996), Krishnadas Academy, Varnasi, $3^{\text {rd }}$ edition, pp: 370.

[8] Inderbir Singh. (2007), Human Embryology, $8^{\text {th }}$ edition, Macmillan Publishers India limited, pp: 37.

[9] Inderbir Singh. (2007), Human 
Embryology, $8^{\text {th }}$ edition, Macmillan Publishers India limited, pp: 38.

[10] Acharya Sushruta. Vaidya Yadavji Trikamji Acharya, Narayanaram Acharya editors. Acharya Dalhana. Sushruta Samhita with Nibandha Sangraha commentary. Varanasi: Chaukhambha Surabharati Prakashan; 2008, pp: 352.

[11] Dr. GD Singhal, Dr. LV Guru, Anatomical \& Obstetric considerations in ancient Indian surgery (1973), BHU press Banaras Hindu University Varanasi, pp: 57.

[12] Inderbir Singh. (2007), Human Embryology, $8^{\text {th }}$ edition, Macmillan Publishers India limited, pp: 54.

[13] Acharya Sushruta.

Vaidya Yadavji Trikamji Acharya, Narayanaram Acharya editors. Acharya Dalhana. Sushruta Samhita with Nibandha Sangraha commentary. Varanasi: Chaukhambha Surabharati Prakashan; 2008, pp: 348.

[14] Acharya Agnivesha. Acharya Charaka, Vaidya Yadavji Trikamji Acharya, editors. Acharya Chakrapani Dutta. Charaka Samhita with Ayurvedadipika Commentary. Varanasi: Chaukha mbha Sanskrit Sansthan; 2008, pp: 738.

[15] Indusree C. Suseelan: Garbha
Poshana Evam Garbha Matru Parathantrata - A Review Article. International Ayurvedic Medical Journal \{online\} 2019. 